Elsevier Editorial System(tm) for

International Journal of Production Economics

Manuscript Draft

Manuscript Number: IJPE-D-17-01465R2

Title: The Effect of Lean Methods and Tools on the Environmental

Performance of Manufacturing Organisations

Article Type: Research paper

Keywords: Autonomation; JIT; Kaizen/CI; Green Lean; TPM; VSM

Corresponding Author: Professor Jose Arturo Garza-Reyes, BSc, PgCert, $\mathrm{MSC}, \mathrm{MBA}, \mathrm{PhD}$

Corresponding Author's Institution: The University of Derby

First Author: Jose Arturo Garza-Reyes, BSc, PgCert, MSc, MBA, PhD

Order of Authors: Jose Arturo Garza-Reyes, BSc, PgCert, MSc, MBA, PhD;

Vikas Kumar; Sariya Chaikittisilp; Kim Hua Tan

Abstract: Evidence suggests that lean methods and tools have helped manufacturing organisations to achieve operational excellence, and in this way meet both traditional and contemporary organisational objectives such as profitability, efficiency, responsiveness, quality, and customer satisfaction. However, the effect of these methods and tools on environmental performance is still unclear, as limited empirical research has been conducted in this field. This paper therefore investigates the impact of five essential lean methods, i.e. JIT, autonomation, kaizen/continuous improvement, total productive maintenance (TPM) and value stream mapping (VSM), on four commonly utilised measures for the compliance of environmental performance, i.e. material use, energy consumption, non-product output, and pollutant releases. A correlation analysis modelled the relationship and effect of these lean methods on the environmental performance of 250 manufacturing organisations around the world. Structural equation modelling (SEM) was used as a second pronged verification approach to ensure the validity of the results. The results indicate that TMP and JIT have the strongest significance on environmental performance, whereas kaizen/continuous improvement only showed an effect on the use of materials and release of pollutants. Autonomation and VSM did not show any impact on environmental performance. The research holds important implications for industrialists, who can develop a richer knowledge on the relationship between lean and green. This will help them formulate more effective strategies for their simultaneous or sequential implementation. The paper extends our knowledge in the lean and green field by helping us to establish and explain the given relationships between five of the most important and commonly used lean methods and the environmental performance of manufacturing organisations. No previous research had considered the studied lean methods and environmental measures of performance. 
Prof. Ou Tang

Linköping Universitet, Linköping, Sweden

\section{RE: $\underline{\text { Submission of a revised version of our article IJPE-D-17-01465.RI }}$}

Dear Prof. Ou Tang

Please, find attached a copy of a second revised version of our article entitled "The Effect of Lean Methods and Tools on the Environmental Performance of Manufacturing Organisations". We are very satisfied with the very positive comments we have now received from the reviewers, and have accordingly addressed the very last issue they have raised. We sincerely hope that now our article is fully ready for acceptance and publication in IJPE. We are very sure that IJPE readers will find our article interesting and useful to advance their own research and the present field. We are also sure that this will become a highly cited article.

We thank you all your support to improve and publish this article in IJPE. Please, if you require further information about the article or anything else, do not hesitate in contact me as soon as possible.

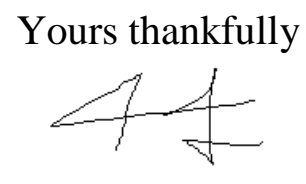

Prof. Jose Arturo Garza-Reyes

Professor of Operations Management

Head of the Centre for Supply Chain Improvement

Derby Business School

The University of Derby

Tel. +44(0)1332593281

E-mail: J.Reyes@derby.ac.uk 


\section{Responses to Reviewers}

\section{Reviewer: 1}

Query 1: The authors have done a nice job with their revision. They have satisfied all but one of my concerns. Both reviewers requested that the authors assess the measurement scales for validity and reliability. The authors have provided Cronbach's alpha values as evidence of reliability and validity. Cronbach's alpha values do provide evidence of reliability but not of validity. I recommend that the authors do a formal assessment of validity (content, convergent, and discriminant). With this final addition, I am prepared to recommend acceptance.

Response: We are thankful to the learned reviewer for his/her useful comments to enhance the quality of this paper. We agree with the reviewer that the Cronbach's Alpha value just provides evidence of reliability. We have therefore now taken your suggestions on board and performed a test for validity. Since the construct items were developed based on an extensive review of the literature, which was further validated through a pilot study with five experts from industry and academia, they thus meet the content validity requirement. We have now calculated the Average Variance Explained (AVE), Composite Reliability (CR), Maximum Shared Variance (MSV) and Average Shared Variance (ASV). For convergent validity, AVE should be $>.50$ and CR should be $>.70$. The analysis shows that our constructs meet the convergent validity (see Table 3). For discriminant validity MSV and ASV should be $<$ AVE. The analysis also shows that the constructs meet the discriminant validity (Table 3). Additions can be seen in Section 3, paragraph in red colour. We sincerely hope that with the inclusion of this analysis we have now addressed all your concerns to your satisfaction. Once more, we truly appreciate all the recommendations you have made through the review cycle of our article. These have contributed for our article be greatly improved in various aspects.

\section{Reviewer 2:}

Query 2: I thank the authors for their work. They have incorporated my comments and addressed successfully my suggestions in the revised manuscript. I still believe that their contribution is minor, but given the early understanding of the relationship between lean and sustainability, and the state of evolution in the area, this work is important and reinforces prior work.

Response: Similarly as with Reviewer 1, we are deeply thankful to the anonymous reviewer for having had a look at our article for the second time. We are also thankful for the positive comments made in regards to the fact that the reviewer considers that all his/her comments have been successfully addressed in our revised manuscript and for considering that our work is important and reinforces previous work in regards to the relationship between lean and sustainability. We sincerely appreciate the anonymous reviewer's support to publish this work, which we are very sure that IJPE readers will find interesting and useful to advance their own research and the present field. We are also sure that this will become a highly cited article. 


\title{
The Effect of Lean Methods and Tools on the Environmental Performance of Manufacturing Organisations
}

\author{
Jose Arturo Garza-Reyes* \\ Centre for Supply Chain Improvement \\ The University of Derby \\ Kedleston Road Campus, Derby, UK, DE22 1GB \\ E-mail: J.Reyes@derby.ac.uk \\ Tel. +44(0)1332593281 \\ Vikas Kumar \\ Bristol Business School \\ University of the West of England \\ Coldharbour Ln, Bristol, UK, BS16 1QY \\ E-mail: Vikas.Kumar@uwe.ac.uk \\ Tel. +44(0)1173283466

\section{Sariya Chaikittisilp} \\ Warwick Manufacturing Group, The University of Warwick \\ International Manufacturing Centre, University of Warwick \\ Coventry, UK, CV4 7AL \\ E-mail: S.Chaikittisilp@warwick.ac.uk
}

\author{
Kim Hua Tan \\ Nottingham University Business School, The University of Nottingham \\ Jubilee Campus, Nottingham, UK, NG8 1BB \\ E-mail: Kim.Tan@nottingham.ac.uk
}

* Corresponding Author 


\section{Highlights}

- The effect of specific lean methods and tools on environmental performance is still unclear

- The impact of five essential lean methods on four commonly utilised measures for the compliance of environmental performance is investigated

- Correlation and structural equation modelling analyses from 250 companies were conducted

- TMP and JIT have the strongest significance on environmental performance

- Kaizen/continuous improvement only showed an effect on the use of materials and release of pollutants

- Autonomation and VSM did not show any impact on environmental performance. 


\begin{abstract}
Evidence suggests that lean methods and tools have helped manufacturing organisations to achieve operational excellence, and in this way meet both traditional and contemporary organisational objectives such as profitability, efficiency, responsiveness, quality, and customer satisfaction. However, the effect of these methods and tools on environmental performance is still unclear, as limited empirical research has been conducted in this field. This paper therefore investigates the impact of five essential lean methods, i.e. JIT, autonomation, kaizen/continuous improvement, total productive maintenance (TPM) and value stream mapping (VSM), on four commonly utilised measures for the compliance of environmental performance, i.e. material use, energy consumption, nonproduct output, and pollutant releases. A correlation analysis modelled the relationship and effect of these lean methods on the environmental performance of 250 manufacturing organisations around the world. Structural equation modelling (SEM) was used as a second pronged verification approach to ensure the validity of the results. The results indicate that TMP and JIT have the strongest significance on environmental performance, whereas kaizen/continuous improvement only showed an effect on the use of materials and release of pollutants. Autonomation and VSM did not show any impact on environmental performance. The research holds important implications for industrialists, who can develop a richer knowledge on the relationship between lean and green. This
\end{abstract}


will help them formulate more effective strategies for their simultaneous or sequential implementation. The paper extends our knowledge in the lean and green field by helping us to establish and explain the given relationships between five of the most important and commonly used lean methods and the environmental performance of manufacturing organisations. No previous research had considered the studied lean methods and environmental measures of performance.

Keywords: autonomation; JIT; kaizen/continuous improvement; green lean; environmental performance; SEM; TPM; VSM.

\section{Introduction}

Lean manufacturing has been widely implemented by manufacturing organisations to achieve operational excellence, and in this way meet both traditional and contemporary organisational objectives such as profitability, efficiency, responsiveness, quality and customer satisfaction (Garza-Reyes, 2015a). Lean methods that enable the achievement of these objectives include just-in-time (JIT), total productive maintenance (TPM), autonomation, value stream mapping (VSM) and kaizen/continuous improvement (CI). Belekoukias et al. (2014) and Rocha-Lona et al. (2013) consider these as the most essential methods of the lean approach. Additionally, Shah and Ward $(2003 ;$ 2007) recognise JIT, TPM, autonomation and kaizen/CI as lean practices that are frequently perceived in the scholarly literature as describing high performance lean manufacturers while Andreadis et al. (2017) and Womack (2006) contemplate VSM as one of the most significant lean methods.

JIT is based on producing the right goods at the right time (Womack and Jones 2003). This contributes in reducing space utilisation, inventory and wastes associated to the overproduction of goods. Commonly linked tools to JIT include pull systems, takt time, one 

2005).

piece flow, levelled production, cell manufacturing, visual control, kanban, JIT purchasing and multifunctional employees (Belekoukias et al., 2014; Rocha-Lona et al., 2014; Kumar, 2010). On the other hand, TPM helps to optimise predictive, preventive and corrective maintenance activities to achieve efficient and proficient production equipment (Konecny and Thun, 2011). TPM relies on tools such as single minute exchange of die (SMED), overall equipment effectiveness (OEE), planned maintenance, 5S, quality maintenance, autonomous maintenance, initial control before starting production, and a safety and hygiene environment (Rocha-Lona et al., 2013; Konecny and Thun, 2011). Furthermore, autonomation, also called jidoka, uses tools such as visual control systems (i.e. andons), a full working system and mistake proofing devices (i.e. poka-yokes) to reduce quality defects (Shingo, 1989). Additionally, VSM is a lean and visual-based method, which illustrates, identifies and measures waste that results from the incapability, inefficiencies and unreliability of money, machines, people, information, space, time, tools and material during a production process (Abdulmalek et al., 2007). This is supported by VSM tools that include flow diagrams and current and future state maps. Finally, CI, or kaizen, is one of the key processes in a lean organisation. The aim of kaizen is to remove waste through the incremental and continuous improvement of operations. Kaizen acts as a platform for the sustainment of lean once that it has been embedded as part of the culture of an organisation. Tools which are commonly associated to the kaizen strategy include 5S, continuous flow, run charts, 5whys, brainstorming, data check sheet, kanban, Pareto chart, Gantt chart, mistake proofing, process maps and VSM (Belekoukias et al., 2014; Rocha-Lona et al., 2013; Bhuiyan and Baghel,

Since its conception several decades ago, lean manufacturing has become the most influential paradigm in manufacturing (Forrester et al., 2010), with strong evidence suggesting it as an effective method to improve the competitiveness of organisations (Hines 
et al., 2004). However, the rise of concerns for the environment has forced manufacturing organisations to not only aim at achieving operational excellence but also to rethink how their operations and processes can become more environmentally sustainable. To this end, and despite some studies (e.g. Zhu et al., 2005), have suggested a relatively week relationship between green practices/performance and operational practices, where lean methods and tools can be considered part of, the study of the simultaneous, or sequential, deployment of lean manufacturing and green operations (hereinafter green) has emerged as a major part of the environmental improvement agenda (Cherrafi et al., 2017; Cherrafi et al. 2016; Garza-Reyes, 2015a; Garza-Reyes, 2015b). For example, Garza-Reyes (2015a) identified and defined, through a systematic literature review, six main research streams in the field of lean and green. These included (1) compatibility between lean and green, (2) their integration, (3) the integration of green lean with other approaches (e.g. six sigma, resilience, agile, etc.), (4) the proposal of measurement methods for green lean, (5) the impact of green lean on various measures of performance (e.g. financial, sustainability, operations, etc.), and (6) the application of green lean in various industrial sectors and organisational functions. Additionally, some limited research has been dedicated to investigate the impact of lean methods and tools on various measures of environmental performance, see Section 2. Nevertheless, the overall effect of lean methods and tools on environmental performance may still be considered inconclusive due to the nature of the research conducted. For instance, the research discussed in Section 2 has been mainly concentrated on very specific lean methods and tools; that is, it has not involved all those which nowadays are recognised as essential components of the lean approach (i.e. JIT, TPM, autonomation, VSM and kaizen/CI) (Belekoukias et al., 2014; Rocha-Lona et al., 2013). In the same way, the measures of environmental performance selected to investigate the effects of lean practices vary considerably from some researches to others. 
Therefore, to complement and expand the limited body of knowledge on the effects that lean manufacturing has on the environmental performance of organisations, this paper investigates the impact of the main methods and tools of lean manufacturing (i.e. JIT, TPM, autonomation, VSM and kaizen/CI) on four commonly utilised measures for the compliance of environmental performance, i.e. material use, energy consumption, non-product output and pollutant releases (National Academy of Engineering, 1999; Ditz and Ranganathan, 1997). These environmental measures are also comparable to some of those employed by Zhu et al. (2008), i.e. reduction of air emission, waste water, solid waste and consumption for hazardous/harmful/toxic materials, to assess the effect of Green Supply Chain Management Practices on the environmental performance of Chinese manufacturers. Considering this, the research question addressed through this research is:

- What is the effect of essential lean tools such as JIT, TPM, autonomation, VSM and kaizen/CI on the environmental performance of manufacturing organisations as measured by the use of material, energy consumption, non-product output and pollutant releases?

The rest of the paper is structured as follows: Section 2 discusses previous works conducted in the field and highlights the gap in the academic literature that this investigation fills; Section 3 presents the research methodology followed to answer the formulated research question; the results of the correlations and structural equation modelling analyses are outlined in Section 4; whereas these are discussed in Section 5; finally, Section 6 provides the concluding remarks, limitations of the research and future research directions derived from it.

\section{Lean manufacturing and its impact on environmental performance}

Climate change, environmental degradation, and natural resources scarcity are some of the major challenges that humankind are currently facing. As major contributors to the conception of such challenges, manufacturing organisation have been forced to develop 
cleaner operations and production processes. One normal starting point for developing better strategies to support environmental sustainability is to explore the opportunities that currently used best practices, e.g. lean, may offer to tackle environmental challenges and how they can be adapted and implemented to meet sustainability requirements. In this context, various authors have conceptually discussed the effects that lean manufacturing methods and tools may have on the environment.

For instance, Vinodh et al. (2011) suggest that lean initiatives stimulate substantial environmental benefits and that, for this reason, companies ought to ponder the environmental impact and quantify sustainable gains associated with lean initiatives. Mollenkopf et al. (2010) advocate that lean companies are more likely to accept environmental innovations. Garza-Reyes (2015b) supports this argument by indicating that the lean's emphasis on waste reduction provides a better atmosphere to implement green initiatives to reduce environmental wastes such excessive consumption of water, energy or any natural resource. In addition, Garza-Reyes (2015b), Garza-Reyes et al. (2014) and Carvalho et al. (2011) mention that some of the waste reduction objectives of lean are 'naturally' aligned to good environmental practices. For example, unnecessary or excessive transportation of products and/or raw materials is one of the seven wastes tackled by lean manufacturing. In this case, when this waste is reduced/eliminated it does not only minimise operational costs but also the unnecessary consumption of natural resources (e.g. oil) and $\mathrm{CO}_{2}$ emissions (Carvalho et al., 2011). This has been empirically shown by Garza-Reyes et al. (2016), who successfully adapted lean manufacturing principles and tools to improve the operational efficiency and environmental performance of the transport operations of a world leader logistics organisation in Mexico. On the other hand, excessive inventory is also considered a waste fiercely tackled by lean as it averts the rapid identification of problems, discourages communication and increases lead time (Hines and Rich, 1997). Inventory 
requires storage, lighting, and in some cases, it also needs to be heated or chilled, all of which have negative environmental implications (Franchetti et al., 2009). Thus, reducing or eliminating inventory as suggested by lean will not only benefit an organisation financially but also environmentally. All this indicates that lean can act as a catalyst for better environmental performance, facilitating companies the deployment of environmental practices and policies.

In contrast to the positive effects of lean on the environment argued by various authors, some contradicting arguments can also be found in the scholarly literature. For example, Cusumano (1994) argues that more frequents deliveries, as advocated by JIT, create traffic congestions and hence more $\mathrm{CO}_{2}$ emissions. Lean also facilitates product variety through more rapid kanban and setup exchanges, as well as more frequent deliveries of smaller lots of components. This is positive from a marketing viewpoint as product variety generates higher demand for goods, the problem is that this crafts the need to dispose replaced products (Cusumano, 1994). This phenomenon may indicate that lean methods and tools may not always, or in all dimensions, have a positive effect on the performance of organisations, and/or that these need to be integrated with contemporary sustainability approaches, e.g. Circular Economy, to offset some of its negative effects on the environment. Finally, other aspects that may contribute to lean not having a positive effect on the environmental performance of organisations may be related to the divergences between lean and green initiatives argued in the scholarly literature. These include how waste is defined and customer expectations (Garza-Reyes, 2015b; Garza-Reyes et al., 2014).

Besides the conceptual discussions presented above regarding the potential effects of the implementation of lean methods and tools on environmental performance, a limited number of scholars have also focused on empirically investigating this phenomenon. For example, King and Lenox (2001) analysed 17,499 U.S. manufacturing establishments between 1991 
and 1996, and found strong evidence that lean, as measured by ISO 9000 adoption and low chemical inventories, is complementary to waste reduction and pollution reduction. Hajmohamad et al. (2013) conducted a study in Canadian manufacturing plants to understand the roles of lean and supply management in regards to improving organisation's environmental performance. The result indicated that the know-how and skills gained when applying lean principles are favourable to the adoption of environmental practices and that those make such practices more effective. Chiarini (2014) studied the environmental impacts of VSM, 5S, cellular manufacturing, SMED and TPM on the production processes of five European companies. The results of the study showed that VSM can identify the environmental impacts of production processes, $5 \mathrm{~S}$ improve waste management and reduces oil leakage, cellular manufacturing can decrease electricity consumption, whereas TPM can reduce oil leakages, and emissions of dusts and chemical fumes into the atmosphere. By contrast, no significant improvements in environmental impacts were observed from implementing SMED. Bandehnezhad et al. (2012) investigated the effect of lean practices in different functional areas of manufacturing firms on environmental performance. Based on a survey of 101 manufacturing organisation in Malaysia, they found that lean practices related to functional areas of process and equipment, human resource, product design and customer satisfaction have positive effects on environmental outcomes. Yang et al. (2011) explored the relationships between lean manufacturing practices, environmental management (e.g. environmental management practices and environmental performance) and business performance outcomes (e.g. market and financial performance). In general, the results of their study suggested that prior lean manufacturing experiences are positively related to environmental management practices. Rothenberg et al. (2001) examined the relationship between lean manufacturing practices and environmental performance, as measured in terms of air emissions and resource use, in 31 automobile assembly plants in North America and 
Japan. The results of the study indicate that lean and the reduction of air emissions of volatile

H: Essential lean methods and tools such as JIT, TPM, autonomation, VSM and kaizen/CI have a significant impact on the environmental performance of manufacturing organisations as measured by commonly employed indicators including material use, energy consumption, non-product output and pollutant releases. 
Lean Methods/Tools

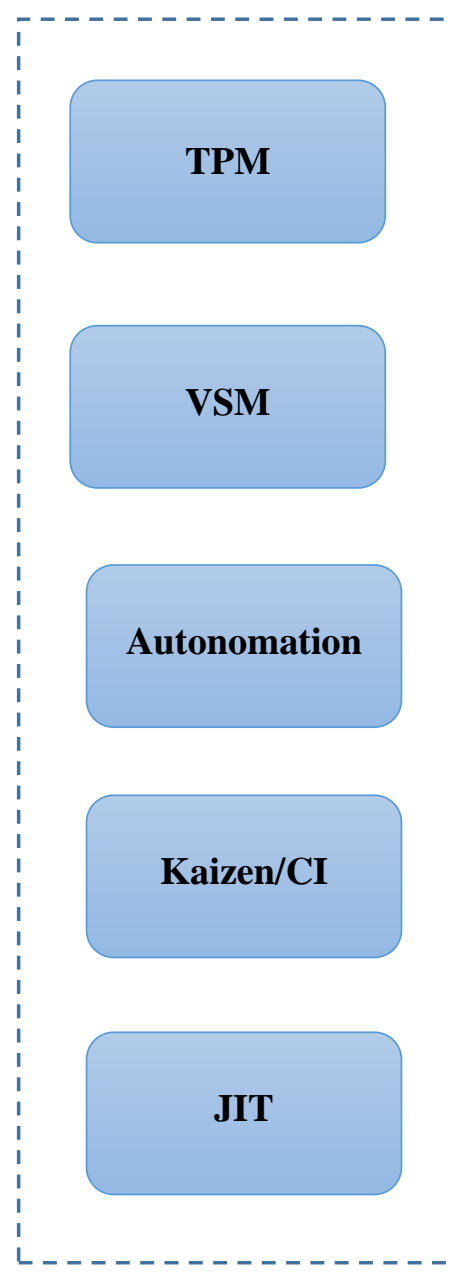

Environmental Performance Measures

$\mathbf{H}$

Energy

Consumption

Non-Product

Output

Pollutant

Releases

Figure 1. Conceptual Framework

\section{Research methodology}

To assess the effect of lean manufacturing on environmental performance, the association between the environmental measures of performance studied (i.e. dependent variable) was determined as an accrual of a number of explanatory independent variables (i.e. lean methods).

A survey questionnaire was designed using Qualtrics software to collect data for performing subsequent statistical analyses. The questionnaire consisted of 9 questions divided into two sections, see Table 1 . Section 1 comprised a set of general profile and 
Section 2

9. Estimate the percentage of the improvement achieved in the following performance indicators due to the implementation of lean.

- Material use - quantities and types of materials used (Ditz and Ranganathan, 1997) - e.g. less material used per unit of product; less water consumption per unit of product; less packing material discharged per unit of product; less hazardous material used in the production process; increase water reused; increase processed, recycled or reused materials, etc.

- Energy consumption - quantities and types of energy used or generated (Ditz and Ranganathan, 1997) - e.g. less energy used per unit of product; less energy used per service or customer; increase in energy saved due to energy conservation, etc.

- Non-product output - quantities and types of waste created

This question intended to examine the level of improvement on environmental performance from implementing lean. This question was correlated with questions 4 to 8 to determine the effect of lean on environmental performance. 


\begin{tabular}{|c|c|c|c|c|c|}
\hline & \multicolumn{5}{|c|}{ Lean Methods } \\
\hline & JIT & TPM & Autonomation & VSM & Kaizen/CI \\
\hline \multirow{12}{*}{ Lean Tools } & One piece flow & OEE & $\begin{array}{l}\text { Mistake } \\
\text { proofing/Poka- } \\
\text { yoke }\end{array}$ & $\begin{array}{l}\text { Current state } \\
\text { map }\end{array}$ & $5 \mathrm{~S}$ \\
\hline & Pull system & SMED & $\begin{array}{l}\text { Andon/visual } \\
\text { control system }\end{array}$ & $\begin{array}{l}\text { Future state } \\
\text { map }\end{array}$ & Brainstorming \\
\hline & Takt time & $5 \mathrm{~S}$ & $\begin{array}{l}\text { Full work } \\
\text { system }\end{array}$ & Flow diagrams & $\begin{array}{l}\text { Continuous } \\
\text { flows }\end{array}$ \\
\hline & $\begin{array}{l}\text { Levelled } \\
\text { production }\end{array}$ & $\begin{array}{l}\text { Autonomous } \\
\text { maintenance }\end{array}$ & & & Kanbans \\
\hline & $\begin{array}{l}\text { Cellular } \\
\text { manufacturing }\end{array}$ & $\begin{array}{l}\text { Planned } \\
\text { maintenance }\end{array}$ & & & Data checks \\
\hline & Visual control & $\begin{array}{l}\text { Quality } \\
\text { maintenance }\end{array}$ & & & 5whys \\
\hline & $\begin{array}{l}\text { Kanban/Pull } \\
\text { production }\end{array}$ & $\begin{array}{l}\text { Initial control } \\
\text { before starting } \\
\text { production }\end{array}$ & & & Pareto chart \\
\hline & $\begin{array}{l}\text { Multifunctional } \\
\text { employees }\end{array}$ & $\begin{array}{l}\text { Safety, hygiene } \\
\text { and the } \\
\text { environment }\end{array}$ & & & Run chart \\
\hline & JIT purchasing & & & & Gantt chart \\
\hline & & & & & VSM \\
\hline & & & & & Process map \\
\hline & & & & & $\begin{array}{l}\text { Mistake } \\
\text { proofing/Poka- } \\
\text { yoke }\end{array}$ \\
\hline
\end{tabular}

This study replicated the methodological approach followed by Belekoukias et al. (2014) for filling and distributing the questionnaire. Thus, the survey targeted operation related executives (e.g. Chief Operating Officers - COOs), operations/production/quality directors/managers, operations/process improvement managers/engineers and lean six sigma black belts who had knowledge on the subject and were familiar with the production processes of their organisations. According to Belekoukias et al. (2014), this type of respondents have both technical expertise on the subject matter and an accurate understanding of the company's performance before and after the deployment of lean. This 
also contributed in reducing the subjectivity of the study as these respondents had a deep and accurate understanding of their company's environmental performance before and after the lean implementation. In order to obtain less subjective and more uniform answers, the respondents were also briefed about various aspects of the questionnaire, including the Likert scale. Following the recommendations of Saunders et al. (2012) and Robson and McCartan (2016) to avoid/minimise any potential biased answers and protect the own personal privacy, interest and integrity of the respondents, the questionnaires were anonymous. Due to the complexity of adding an extra variable like 'time' to the analysis, the time taken by the surveyed organisations to sustain and/or reach the improvements achieved was not considered within the scope of the study. This 'extra-variable' can, however, be considered part of the future research agenda proposed from this study.

Besides the strategies employed to avoid biased answers, the questionnaire was validated, as suggested by Robson and McCartan (2016) and Groves et al. (1999), through a small-scale pilot study with experts. In this case, five experts from industry and academia where requested to check the questionnaire for reliability threats such as subject or participant error, subject or participant bias, observer error and observer bias (Robson and McCartan, 2016). Participant error and bias were further addressed by eliminating ambiguous and irrelevant questions (Binti Aminuddin et al., 2015). Experts also provided feedback on structural, presentation and linguistic aspects of the questionnaire and whether additional questions were needed to meet the objectives of the research. Observer error and bias were irrelevant to the questionnaire as fixed-alternative questions that did not require interpretation were used (Binti Aminuddin et al., 2015). Some questions were rectified and clarified further as a results of the pilot study.

Since this was an explanatory study, the questionnaires were distributed to respondents working in the manufacturing industry worldwide. The questionnaires were distributed via 
LinkedIn as a primary channel. In this line, 618 questionnaires were distributed directly through personal messages to lean experts (i.e. Chief Operating Officers - COOs), operations/production/quality directors/managers, operations/process improvement managers/engineers and lean six sigma black belts, along with a cover letter introducing the research and indicating its purpose. Additionally, the questionnaires were forwarded via emails to personal contacts of the authors. To broaden the pool of respondents, personal contacts were also requested to push forward the questionnaire to their own networks, producing in this way a 'snowballing sampling technique' (Horwitz et al., 2006). When initially contacted, the potential respondents were asked whether their organisations had implemented lean and whether they considered it as the main operations improvement strategy deployed by their companies. If the answer was positive to both of these questions, then the questionnaire was administrated to the respondent. Otherwise, the organisation was considered not suitable for the study. Out of the more than 618 questionnaires distributed, 250 responses were obtained. This sample size was considered acceptable, based on comparative studies in similar fields (e.g. Kirkham et al. 2014; Binti Aminuddin et al., 2015; Tachizawa and Gimenez, 2010; Kumar et al. 2014), to meet the objectives of this research and address the research question previously formulated.

To test the validity and reliability of the measurement scales used in this paper, firstly a Cronbach's Alpha test was conducted to test the reliability of the constructs. The test findings are shown in Table 3, which shows that all values are within the acceptable ranges $(>=0.70)$. To test the constructs for convergent validity, the Average Variance Explained (AVE) factor was calculated. This AVE factor should be $>0.5$ to ensure such validity of the constructs. Additionally, the Composite Reliability (CR) was also computed. In this case, to ensure the Composite Reliability of the constructs CR should be $>.70$. As indicated by Table 3, AVE values for all the constructs were $>0.5$ and $\mathrm{CR}$ values were $>0.70$. This confirmed both the 
Table 3. Reliability, Convergent Validity and Discriminant Validity

\begin{tabular}{|c|c|c|c|c|c|c|}
\hline Constructs & $\begin{array}{l}\text { No. of } \\
\text { Items }\end{array}$ & AVE & $\begin{array}{c}\text { Composite } \\
\text { Reliability } \\
\text { (CR) }\end{array}$ & $\begin{array}{c}\text { Cronbach's } \\
\text { Alpha }\end{array}$ & MSV & ASV \\
\hline VSM & 3 & 0.69 & 0.74 & 0.71 & .429 & .280 \\
\hline Kaizen & 12 & 0.55 & 0.86 & 0.82 & .452 & .362 \\
\hline Autonomation & 3 & 0.59 & 0.74 & 0.70 & .279 & .233 \\
\hline TPM & 8 & 0.53 & 0.79 & 0.74 & .311 & .246 \\
\hline JIT & 9 & 0.54 & 0.79 & 0.81 & .452 & .332 \\
\hline
\end{tabular}

Table 4. Harman's single factor score test (Total Variance Explained)

\begin{tabular}{|c|c|c|c|c|c|c|}
\hline \multirow[b]{2}{*}{ Component } & \multicolumn{3}{|c|}{ Initial Eigenvalues } & \multicolumn{3}{|c|}{ Extraction Sums of Squared Loadings } \\
\hline & Total & $\%$ of Variance & Cumulative $\%$ & Total & $\%$ of Variance & Cumulative $\%$ \\
\hline 1 & 3.274 & 36.372 & 36.372 & 3.274 & 36.372 & 36.372 \\
\hline 2 & 2.801 & 31.125 & 67.498 & & & \\
\hline 3 & 617 & 6.850 & 74.348 & & & \\
\hline 4 & .586 & 6.513 & 80.861 & & & \\
\hline 5 & .526 & 5.840 & 86.701 & & & \\
\hline 6 & .384 & 4.266 & 90.967 & & & \\
\hline 7 & .342 & 3.796 & 94.763 & & & \\
\hline 8 & .268 & 2.983 & 97.746 & & & \\
\hline
\end{tabular}




\section{Results}

The findings presented in this section are based on the 250 valid responses obtained from the survey. The first section of the survey provided a profile and demographics' overview of the respondents and their organisations. In this line, over $73 \%$ of the respondents were employed by large organisations (i.e. $>250$ employees), whereas over $17 \%$ and $9 \%$ worked for medium side (i.e. between 50 and 250 employees) and small organisations (i.e. $<50$ employees) respectively.

In terms of their locations, $54.40 \%$ of the respondents' companies were operating in Europe, $20.40 \%$ in Asia, 20\% in North America, $8.80 \%$ in South America, $4.40 \%$ in Africa, and $3.20 \%$ in Australia. Respondents were allowed to select more than one continent if their companies operated in various continental locations. The respondents' organisations competed in various manufacturing sectors such as transportation equipment $(10.80 \%)$, 
Table 5. Correlation results

\begin{tabular}{lllll}
\hline & Materials use & $\begin{array}{l}\text { Energy } \\
\text { consumption }\end{array}$ & $\begin{array}{l}\text { Non-product } \\
\text { output }\end{array}$ & Pollutant releases \\
\hline Kaizen/CI & $.198^{* *}$ & .095 & .117 & $.163^{*}$ \\
VSM & -.008 & -.031 & .053 & .013 \\
Autonomation & .069 & .073 & .051 & .097 \\
TPM & $.254^{* *}$ & $.226^{* *}$ & $.253^{* *}$ & $.227^{* *}$ \\
JIT & $.225^{* *}$ & $.177^{* *}$ & $.218^{* *}$ & $.209^{* *}$ \\
\hline
\end{tabular}

**. Correlation is significant at the 0.01 level (2-tailed).

*. Correlation is significant at the 0.05 level (2-tailed).

In terms of material use, the correlation analysis, see Table 5, showed a statistically significant relationship between JIT $\left(0.254^{* *}\right)$, kaizen/CI $\left(0.225^{* *}\right)$ and TPM $\left(0.198^{* *}\right)$ with this measure of environmental performance at a 0.01 level (2-tailed) of significance. The analysis also indicated that material use is not affected by the autonomation and VSM lean 
methods. For energy consumption, the correlation analysis suggested that only TPM $\left(0.226^{* *}\right)$ and $\operatorname{JIT}\left(0.177^{* *}\right)$ have a statistically significant effect on this measure of environmental performance at a significant level of 0.01 level (2-tailed), whereas kaizen, autonomation and VSM do not.

When focusing on non-product output, see Table 5, the correlation analysis showed that similar to energy consumption, this environmental performance measure is strongly and positively affected by the TPM $\left(0.253^{* *}\right)$ and JIT $\left(0.218^{* *}\right)$ methods at a 0.01 level (2-tailed) of significance. In this case, the rest of the lean methods studied (i.e. kaizen/CI, autonomation and VSM) do not have any major effect on non-product output according to the results of the correlation analysis. Finally, the correlation analysis indicated that in reference to pollutant releases, the TPM $\left(0.227^{*}\right)$ and JIT $\left(0.209^{* *}\right)$ lean methods have a strong effect on this environmental measure of performance at a significant level of 0.01 level (2-tailed) while kaizen/CI $\left(0.163^{*}\right)$ presents the same level of impact but at 0.05 level (2-tailed) level of significance.

Table 6 illustrates and summarises the results of the correlation analysis and the strength of the impact of the lean methods studied on the four measures of environmental performance. For instance, Table 6 indicates that although all three TPM, JIT and kaizen/CI have a statistically significant impact on the use of materials, the strongest effect is that of TPM, followed JIT and kaizen/CI. For the same example, Table 6 also specifies that autonomation and VSM do not have any effect on materials use as the correlation analysis did not show any statistical significance between these variables. From Table 6, and the correlation analysis presented in Table 5, it is evident that TPM and JIT are the lean methods that have the strongest effect on environmental performance, followed by kaizen/CI. On the other hand, VSM and autonomation do not seem to have any impact on these environmental performance measures. Therefore, the result of the correlation analysis suggest that actions to 
Table 6. Illustration and summary of correlation results

\begin{tabular}{|c|c|c|c|c|}
\hline & Materials use & $\begin{array}{l}\text { Energy } \\
\text { consumption }\end{array}$ & $\begin{array}{l}\text { Non-product } \\
\text { output }\end{array}$ & Pollutant releases \\
\hline Kaizen/CI & + & 0 & 0 & + \\
\hline VSM & 0 & 0 & 0 & 0 \\
\hline Autonomation & 0 & 0 & 0 & 0 \\
\hline TPM & +++ & +++ & +++ & +++ \\
\hline JIT & ++ & ++ & ++ & ++ \\
\hline
\end{tabular}

To cross verify the findings of the correlation analysis, the SEM technique was applied. The structural equation model focused on analysing the impact of each of the five lean methods studied on the four environmental performance measures. Therefore, four SEM models, see Figures 2(a), 2(b), 2(c) and 2(d), were constructed. The fitness indices of the best-fit model, for each environmental performance measure are shown in Table 7, which shows that all of them are within acceptable ranges. It is evident that the SEM models verify the correlation findings, for example, for material use, the best-fit model confirms a positive relationship with TPM, JIT and kaizen/CI and the absence of a significant relationship of this environmental measure with autonomation and VSM, see Figure 2(a). Thus, the SEM model corroborates the overall findings of the correlation analysis by showing that TPM and JIT affect all the four environmental performance measures, whereas kaizen/CI only have an impact on materials use and pollutant releases while VSM and autonomation do not show any impact on any of the performance measures. 


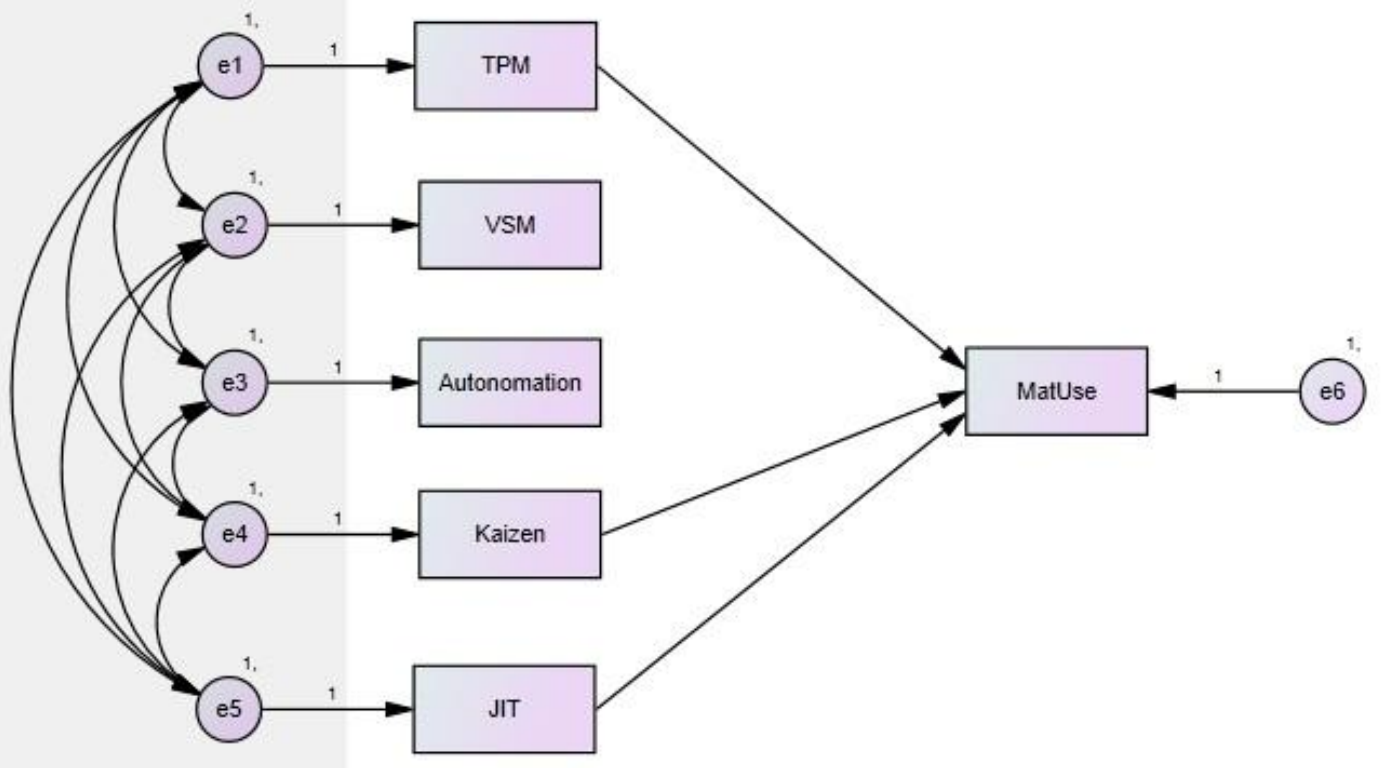

(a)

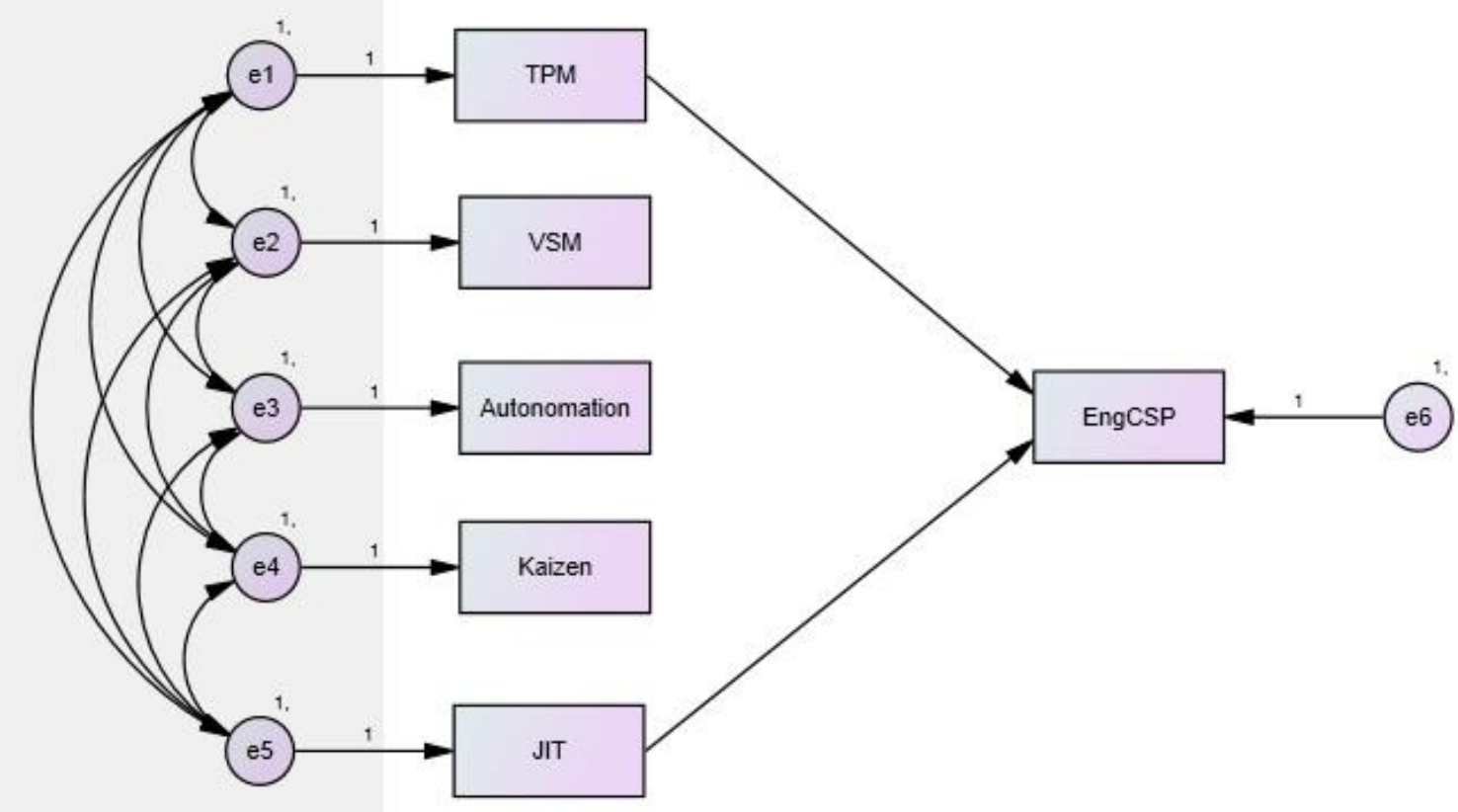

(b) 


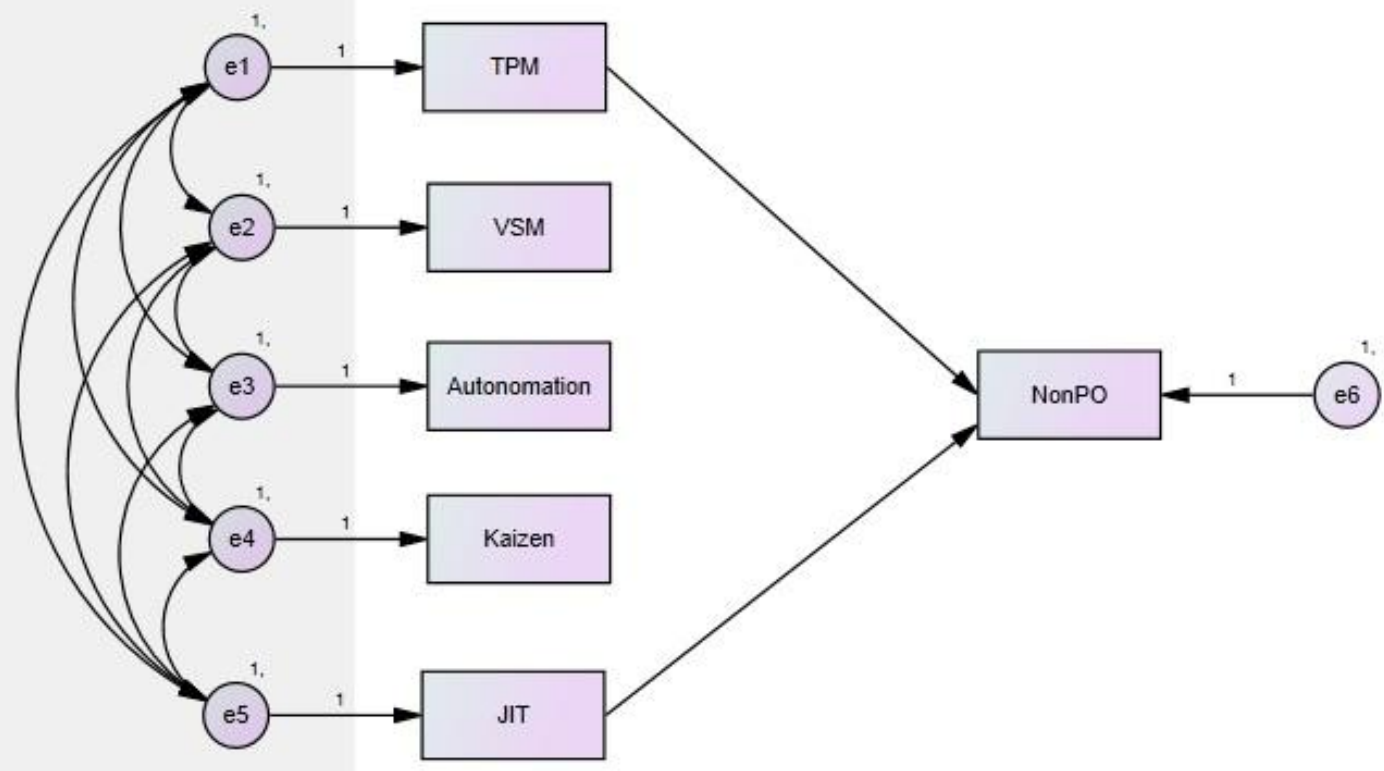

(c)

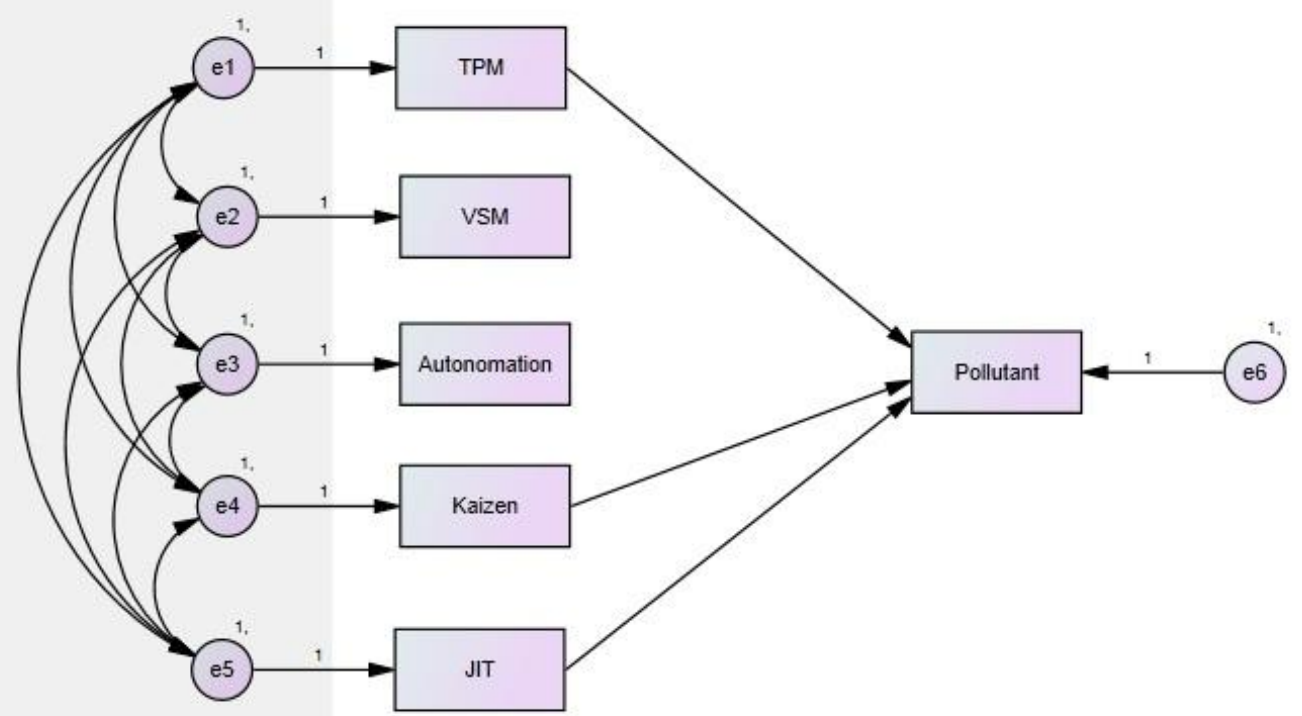

(d)

Figure 2. Best-fit model for (a) Material use, (b) Energy consumption, (c) Non-product output, and (d) Pollutant releases 
Table 7. Fitness indices for best-fit path models

\begin{tabular}{lcccccc}
\hline $\begin{array}{l}\text { Best Fit Model/Fitness } \\
\text { Indices }\end{array}$ & $\begin{array}{c}\text { NFI } \\
(>\mathbf{9 0})\end{array}$ & $\begin{array}{c}\text { RFI } \\
(>\mathbf{9 0})\end{array}$ & $\begin{array}{c}\text { IFI } \\
(\approx \mathbf{1})\end{array}$ & $\begin{array}{c}\text { CFI } \\
(\boldsymbol{\approx 1})\end{array}$ & RMSEA & CMIN/DF \\
\hline Non-product output & .994 & .961 & 1.000 & 1.000 & .005 & 1.007 \\
Pollutant releases & .992 & .921 & .996 & .996 & .064 & 2.017 \\
Materials use & .985 & .845 & .989 & .989 & .110 & 3.997 \\
Energy Consumption & .987 & .912 & .993 & .993 & .070 & 2.231 \\
\hline
\end{tabular}

\section{Discussion of results}

\subsection{Material use measure}

The correlation and SEM analyses suggested that TPM, JIT and kaizen/CI have a positive effect on the use of materials while autonomation and VSM do not, see Tables 5-7.

In the case of TPM, it intends to improve the performance and conditions of production equipment (Konecny and Thun, 2011). Thus, it is understandable to assume that TPM will have a positive effect on the use of material as production equipment that runs at an optimum condition will process raw material more efficiently and with less waste (Eti et al., 2004). Jasiulewicz-Kaczmarek (2014) comments that TPM provides a strict control on the functioning of production equipment, which reduces unplanned failures and human errors that in many cases result in raw material being wasted. Also, the material/resources used to run production equipment are reduced by TPM. For example, Chiarini (2014) empirically found that TPM helps to reduce oil leakages. Fliedner (2008) suggests that TPM's 5S achieves a well-organised, cleaned, developed and sustained work place. Thus, this tool assists in a faster identification of spills and leaks, contributing in this way to the reduction of unnecessary material consumption. Furthermore, it can reduce materials and chemicals' usage due to well-organised equipment, materials and parts. Keeping the floor clean to clearly expose any leak in a system is also one of the $5 \mathrm{~S}$ characteristics that have a positive impact on reducing waste of material (Torielli et al., 2011).

The positive effect of JIT on the use of material was found to be the second most significant, see Table 6. It is well established in the academic literature that JIT has a 
significant and positive effect on quality by reducing inventory and consequently exposing problems (Belekoukias et al., 2014; Cua et al., 2006). Subsequently, it is also well established that quality reduces the consumption of material by eliminating/reducing scrap and rework (Shingo, 1989). This indicates that JIT can have a positive effect on the consumption of material through quality. In addition, as previously discussed, by reducing inventory, the use of other resources/materials needed to safely store inventory, e.g. electricity or gas, can be reduced (Franchetti et al., 2009). Garza-Reyes et al. (2016) also suggest that by following the JIT's advice of having smaller deliveries, smaller vehicles can be utilised, resulting in less fuel consumption.

In the case of kaizen, the results obtained from this study are in line with what it has been strongly stated in the academic literature regarding the positive effects of this lean method on the use of material. Farish (2009) comments that Toyota has actively adopted kaizen to minimize environmental effects like disposals to landfill, use of energy and water. Additionally, Vais et al. (2006) empirically demonstrated that the implementation of lean techniques such as 5S, kaizen and autonomous maintenance can enhance environmental performance by optimising ecological resources consumption and production output. Other authors such as Pampanelli et al. (2011) and Ross and Associates (2000) have also suggested that kaizen/CI can be used to enhance sustainability, especially through the reduction of material consumption. Therefore, the positive effect of TPM, JIT and kaizen/CI on material use found in this study seems to be aligned to these conceptual and empirical evidence presented.

In contrast, the correlation and SEM analyses did not only indicate a non-effect of autonomation and VSM on the use of material but also on all the other measures of environmental performance, i.e. energy consumption, non-product output and pollutant releases. Autonomation's main objective is to improve quality by preventing quality defects 
(Shingo, 1989). Following the same reasoning for JIT regarding the positive effect of quality on the use of material, a positive effect of autonomation on this measure would have been expected. However, the results of this study contradict this reasoning, and the notion that some autonomation tools such as visual control systems can contribute in reducing material consumption and improving sustainability (Bandehnezhad et al., 2012; Vinodh et al., 2011). However, Biggs (2009) considers that visual control tends to have more side-effects on environmental performance than direct interventions. This may be one of the reasons as to why this study did not find a positive effect of this lean method on material use, or any of the other measures of environmental performance, see Tables 5-7. To have an effect on environmental performance, Tice et al. (2005) suggest that standard work and visual controls should be integrated with energy management systems (EMS) responsibilities and processes.

In the case of VSM, Abdulmalek et al. (2007) state that its main objective is to identify waste in manufacturing systems. The current state VSM identifies value-added and non-value added activities in transformational processes. Since some environmental wastes are embedded in the seven lean wastes (Garza-Reyes, 2015a; Garza-Reyes et al., 2014; Carvalho et al., 2011), it can be implied that identifying wastes in a manufacturing system through a VSM can have a positive impact on environmental performance. Fliedner (2008) agrees that VSM magnifies the benefits of environmental performance through less scrap and energy consumption. Chiarini (2014) found that VSM can be applied to investigate the environmental effects of manufacturing processes. Kurdve et al. (2011) successfully adapted the traditional VSM into an environmental-VSM to focus, particularly, on identifying environmental wastes. However, the results of this study contradict these notions but support those from Venkat and Wakeland (2006) and Brown et al. (2014), who suggest various limitations of this lean method when used for the improvement of environmental performance. Based on the practical and research experience of the authors, we are convinced 
of the potential value and effectiveness of kaizen/CI, autonomation and VSM to not only reduce material consumption but also reduce energy consumption, non-product output and pollutant releases. Since the results of this study contradict some of the literature and our experience, further studies in relation to the effect of these lean methods on environmental performance are suggested as part of the future research agenda.

\subsection{Energy consumption}

TPM was found to have the strongest effect on the reduction of energy consumption, followed by JIT, see Table 6. Equipment operating at an optimum condition will be more efficient and hence will consume less energy (Eti et al., 2004). Also, TPM can reduce nonvalue adding energy use from lighting, heating and cooling during a machine's standby as well as reducing the non-value adding energy which in some cases is needed to re-start some equipment after a breakdown. In an empirical study, Chiarini (2014) found that TPM helps to turn off the use of energy in a cell and in equipment in general, which lowers non-value adding standby energy use. Thorough the same study, Chiarini (2014) also found that the TPM's tool SMED contributed in reducing electricity consumption in some manufacturing equipment, although this was not significant. Torielli et al. (2011) suggest that the TPM's tool $5 \mathrm{~S}$ can promote energy efficiency by taking care of the machines and items' standard operating procedures as well as developing indicators to show the correct status of a system. In the case of JIT, since it reduces inventory's volume (Shingo, 1989), it can help to reduce the energy required to safely store it (Franchetti et al., 2009). In addition, Chiarini (2014) found that by grouping machines, staff and workplaces dedicated to similar products in a single cell (i.e. JIT's cellular manufacturing) the transportation of material is greatly reduced, resulting in a significant reduction of energy consumption of electric trucks used to move material within a factory. In summary, all this evidence suggests that both TPM and JIT can 
have a positive effect on the reduction of energy in manufacturing environments. This is aligned to the results obtained in this study.

In reference to kaizen/CI, autonomation and VSM, the results of the correlation and SEM analyses on energy consumption are the same as for that of materials use, except for kaizen/CI, which showed some moderate effect on material use. The possible reasons for these three lean methods not having an effect on energy consumption, see Tables 5-7, may be similar to those highlighted in the aforementioned discussion in the material use section.

\subsection{Non-product output}

Similarly as in the case of energy consumption, TPM and JIT were found to have a positive effect on non-product output while kaizen/CI, autonomation and VSM were not, see Tables 5-7. Fliedner (2008) comments that TPM is primarily responsible for enhancing the reliability and durability of equipment and, at the same time, reducing spillages and leakages. This results in the reduction of solid and hazardous waste (Fliedner, 2008). Eti et al. (2004) also mention that equipment failures can adversely affect the quality of the end-product, not only contributing in this way to wasting materials, see Section 5.1, but also producing scrap. These views are in line with the results obtained from this study. However, TPM may still have some adverse environmental effects in this category as King and Lenox (2001) argue that the TPM's tool SMED increases the number of cleaning products, which leads to raising disposal of unwanted materials. This, however, is not reflected through the results of this study. In the case of JIT, a case study carried out by Ross and Associates (2004) revealed that JIT can reduce the disposal of out-of-date products that result from excessive inventory and the introduction of new product versions or lack of demand. Additionally, Fliedner (2008) suggests that the JIT's pull system can cut down inventory during and post process, reducing in this way the damage and deterioration of products and hence improving green performance. 
Although the nature of kaizen/CI, autonomation and VSM may suggest that all of these lean methods would contribute in reducing non-product output through the identification and elimination of waste as well as the improvement of quality and efficiency (Abdulmalek et al., 2007; Bhuiyan and Baghel, 2005; Shingo, 1989), their effective implementation, management and sustainment may also play a critical role in their contribution to enhance environmental performance. This may have acted as a barrier for the studied organisations to experience the theoretical environmental benefits that these approaches may contribute with.

\subsection{Pollutant releases}

Pollutant releases have been widely used as a measure of green performance (King and Lenox, 2001). In this case, the study found that TPM, JIT and kaizen/CI have a positive effect on pollutant releases, whereas autonomation and VSM do not, see Tables 5-7. Through an empirical investigation, Chiriani (2014) found that TPM strongly contributed in reducing dusts and fumes in five manufacturing organisations. This came as a result of a more effective maintenance of the filters, piping and chimney of production equipment (Chiriani, 2014). Torielli et al. (2011) comment that the TPM's 5S tool pays attention to uncontrolled waste or emissions due to the fact that they do not fit within the standard. Despite the lack of further research on the effect of maintenance, and TPM, on environmental performance, and specifically on pollutant releases, it is not difficult to assume that well maintained production equipment will operate at an optimum level, reducing the emissions of harmful gases to the atmosphere, including $\mathrm{CO}_{2}$. In the case of JIT, there seems to be some contraction regarding its effect on the reduction of pollutant releases. For instance, Venkat and Wakeland (2006) comment that delivering smaller batches increases the frequency of transportation, which generates a greater amount of $\mathrm{CO}_{2}$ emissions. Also, using larger batches, for example, when painting cars with the same colour can diminish the emissions of air pollutant, but this approach contradicts the JIT's principle (Rothenberg et al., 2001). In this case, the results of 


\section{Concluding remarks, limitations and future research directions}

This paper investigates the relationship and impact that some of the most essential lean methods (i.e. JIT, TPM, autonomation, VSM and kaizen/CI) have on four commonly utilised measures for the compliance of environmental performance (i.e. material use, energy consumption, non-product output and pollutant releases). The study uses a two pronged verification approach by using the correlation and SEM methods to ensure the validity of the results. Therefore, this study fills a research gap as previously established in Sections 1 and 2, and extends our knowledge in the lean and green field by:

- Exploring and helping us to better understand the effect that the implementation of lean manufacturing has on the environmental performance of manufacturing organisations;

- Defining the degree of strength of the effect of the lean methods JIT, TPM, autonomation, VSM and kaizen/CI on the use of material, consumption of energy, production of nonproduct output, and release of pollutants. No previous studies had considered all the same lean methods and environmental measures of performance investigated in this study; and

- Explaining the given relationships and effects. 
These contributions are beneficial for manufacturing managers who aim to gain a better have on the environmental performance of their operations. Therefore, our study provides a good insight of these relationships that can assist managers to take better decisions and formulate more effective strategies for the simultaneous, or sequential, implementation of lean, and environmental practices. This will help them to aim at not only improving profitability, efficiency, responsiveness, quality, and customer satisfaction, but also comply with environmental regulations and contribute to tackle some of the major challenges currently faced by humankind such as climate change, environmental degradation, and natural resources scarcity. Due to the need of organisations in other sectors, besides manufacturing, such as logistics and transport, healthcare, services, among others, to achieve these objectives, and the wider applicability of lean and green, other industries can also benefit from this study. Like the manufacturing industry, all these sectors are under intense pressure to operate competitively while at the same time making sure that their operations meet the environmental sustainability needs of the wider society. The effective implementation of green lean can provide them with an opportunity to achieve this endeavour.

Overall, the paper provides some interesting insight into the effects of lean manufacturing on environmental performance. This may encourage organisations not currently embarked or fully committed to sustainability to contemplate the business benefits that green lean may bring to their operations. Therefore, the paper provides trustworthy evidence for practitioners of the relationship between lean and environmental performance and can guide them to prioritise the deployment of lean methods based on the environmental performance measures they consider more strategically important to improve. 


\section{References}

Various constraint factors which limited the extent and scope of the research, and its results, were encountered. These are important to be highlighted in order for future studies to consider them and to define the agenda for future research. Firstly, the study was carried out within the boundaries of the manufacturing sector only. Thus, further research is needed to provide added insights of the effect of lean manufacturing, and it methods, on the environmental performance of organisations operating in other industrial sectors. This will shed further light on the role that industry characteristics may have on the effect of lean manufacturing impact on environmental performance. Secondly, the study excluded academic experts as it was only focused on industrial experts. In future research, similar work can also be underpinned by academic and research experts in the field and not only by pragmatic sources. Thirdly, due to the strategy and structure followed in this paper to collect data, this study also suffers from the fact that the Likert-style rating scale for the survey limits the ability of respondents to express opinions other than the pre-set answers. To overcome this limitation, future research can be coupled with qualitative interviews with selected companies. This will also contribute in validating the results further. Finally, in this research, the effect of lean methods was investigated in reference to one of the pillars of sustainability, i.e. environment. Plenty of research has also been carried out in relation to the effect of lean on the profit pillar of sustainability. However, very limited research has investigated the effect of lean implementation on the societal dimension of sustainability. This is part of the future research agenda derived from this research and we encourage researchers to take steps in this direction. 
Abdulmalek, F.A., Rajgopal, J. (2007), “Analyzing the benefits of lean manufacturing and value stream mapping via simulation: A process sector case study", International Journal of Production Economics, 107(1), 223-236.

Andreadis, L., Garza-Reyes, J.A., Kumar, V. (2017), “Towards a conceptual framework for Value Stream Mapping (VSM) implementation: An investigation of managerial factors", International Journal of Production Research, 55(23), 7073-7095.

Bandehnezhad, M., Zailani, S., Fernando, Y. (2012), “An empirical study on the contribution of lean practices to environmental performance of the manufacturing firms in northern region of Malaysia”, International Journal of Value Chain Management, 6(2), 144168.

Belekoukias, I., Garza-Reyes, J.A., Kumar, V. (2014), “The impact of lean methods and tools on the operational performance of manufacturing organisations", International Journal of Production Research, 52(18), 5346-5366.

Bhuiyan, N., A. Baghel (2005), “An Overview of Continuous Improvement: From the past to the Present", Management Decision, 43(5), 761-771.

Biggs, C. (2009), Exploration of the integration of lean and environmental improvement, PhD Thesis, Cranfield University, UK.

Binti Aminuddin, N.A., Garza-Reyes, J.A., Kumar, V., Antony, J. (2016), “An analysis of managerial factors affecting the implementation and use of Overall Equipment Effectiveness", International Journal of Production Research, 54(15), 4430-4447.

Brown, A., Amundson, J., Badurdeen, F. (2014), "Sustainable value stream mapping (SusVSM) in different manufacturing system configurations: application case studies", Journal of Cleaner Production, 85, 164-179.

Carvalho, H., Duarte, S. and Cruz-Machado, V. (2011), "Lean, agile, resilient and green: divergences and synergies", International Journal of Lean Six Sigma, 2(2), 151-179. 
Cherrafi, A., Elfezazi, S., Chiarini, A., Mokhlis, A., Benhida, K. (2016), “The integration of lean manufacturing, Six Sigma and sustainability: a literature review and future research directions for developing a specific model", Journal of Cleaner Production, $139,828-846$.

Cherrafi, A., El Fezazi, S., Govindan, K., Garza-Reyes, J.A., Mokhlis, A., Benhida, K. (2017), "A framework for the integration of Green and Lean Six Sigma for superior sustainability performance", International Journal of Production Research, 55, 15, $4481-4515$.

Chiarini, A. (2014), "Sustainable manufacturing-greening processes using specific lean production tools: an empirical observation from European motorcycle component manufacturers", Journal of Cleaner Production, 85, 226-233.

Cua, K.O., McKone-Sweet, K.E., Schroeder, R.G. (2006), “Improving Performance through an Integrated Manufacturing Program”, Quality Management Journal, 13(3), 45-60.

Cusumano, M.A. (1994), “The limits of lean”, Sloan Management Review, 35(4), 27-32.

Ditz, D., Ranganathan, J. (1997), Measuring up: toward a common framework for tracking corporate environmental performance, World Resources Institute, Washington, D.C.

Eti, M.C., Ogaji, S.O.T., Probert, S.D. (2004), "Implementing total productive maintenance in Nigerian manufacturing industries", Applied Energy, 79(4), 385-401.

Farish, M. (2009), "Plants that are green [Toyota's lean manufacturing]", Engineering \& Technology, 4(3), 68-69.

Fliedner, G. (2008), "Sustainability: a new lean principle", Proceedings of the 39th annual meeting of the decision sciences institute, Baltimore, Maryland, 3321-3326.

Forrester, P., Shimizu, U., Soriano-Meier, H., Garza-Reyes, J.A., Basso, L. (2010), “Lean Production, Market Share and Value Creation in the Agricultural Machinery Sector in Brazil”, Journal of Manufacturing Technology Management, 21(7), 853-871. 
Franchetti, M., Bedal, K., Ulloa, J. and Grodek, S. (2009), "Lean and green: industrial engineering methods are natural stepping stones to green Engineering”, Industrial Engineer, 41(9), 24-29.

Garza-Reyes, J.A., Winck Jacques, G., Lim, M.K., Kumar, V., Rocha-Lona, L. (2014), "Lean and green - synergies, differences, limitations, and the need for Six Sigma", in B. Grabot et al. (Eds.): International Conference on Advances in Production Management Systems (APMS) 2014, Part II, IFIP AICT 439, Ajaccio, France, 20-24 September, Springer.

Garza-Reyes, J.A. (2015a), "Lean and Green - A systematic review of the state of the art literature", Journal of Cleaner Production, 102, 18-29.

Garza-Reyes, J.A. (2015b). "Green Lean and the need for Six Sigma”, International Journal of Lean Six Sigma, 6(3), 226-248.

Garza-Reyes, J.A., Villarreal, B., Kumar, V., Molina Ruiz, P. (2016), “Lean and Green in the Transport and Logistics Sector - A Case Study of Simultaneous Deployment”, Production Planning \& Control, 27(15), 1221-1232.

Groves, R.M., Fultz, N., Martin, E. (1991), "Direct questioning About Comprehension in a survey setting”, Public Opinion Quarterly, 56, 475-495.

Hajmohamad, S., Vachon, S, Klassen, R.D., Gavronski, I. (2013), "Lean management and supply management: their role in green practices and performance", Journal of Cleaner Production, 39, 312-20.

Hines, P., Rich, N. (1997), “The seven value stream mapping tools", International Journal of Operations and Production Management, 17(1), 46-64.

Hines, P., Holweg, M., Rich, N. (2004), "Learning to evolve: a review of contemporary lean thinking”, International Journal of Operations \& Production Management, 24(10), 994-1011. 
Horwitz, F.M., Bravington, D., Silvis, U. (2006), “The promise of virtual teams: identifying key factors in effectiveness and failure", Journal of European Industrial Training, 30(6), 472-494.

Jasiulewicz-Kaczmarek, M. (2014) "Integrating lean and green paradigms in maintenance management", IFAC Proceedings Volumes, 47(3), 4471-4476.

King, A.A., Lenox, M.J. (2001), "Lean and green? An empirical examination of the relationship between lean production and environmental performance", Production Operations Management, 10(3), 244-256.

Kirkham, L., Garza-Reyes, J.A., Kumar, V., Antony, J. (2014), "Prioritisation of operations improvement projects in the European manufacturing industry", International Journal of Production Research, 52(18), 5323-5345.

Klassen, R.D. (2000), “Just-in-Time manufacturing and pollution prevention generate mutual benefits in the furniture industry", Journal Interfaces, 30(3), 95-106.

Konecny, P.A., Thun, J.H. (2011), "Do it separately or simultaneously-An empirical analysis of a conjoint implementation of TQM and TPM on plant performance”, International Journal of Production Economics, 133(2), 496-507.

Koufteros, X. A. 1999. “Testing a Model of Pull Production: A Paradigm for Manufacturing Research Using Structural Equation Modeling”, Journal of Operations Management, 17(4), 467-488.

Kumar, V. (2010), “JIT Based Quality Management: Concepts and Implications in Indian Context”, International Journal of Engineering Science and Technology, 2(1), 40-50.

Kumar, M., Khurshid, K.K., Waddell, D. (2014), "Status of quality management practices in manufacturing SMEs: a comparative study between Australia and the UK", International Journal of Production Research, 52(21), 6482-6495. 
Kumar, V., Smart, P.A., Maddern, H. Maull, R.S, (2008), "Alternative perspectives on service quality and customer satisfaction: the role of BPM", International Journal of Service Industry Management, 19(2), 176 - 187

Kumar, V., Batista, L., Maull, R. (2011), “The impact of operations performance on customer loyalty", Service Science, 3(2), 158-171.

Kurdve, M., Hanarp, P., Chen, X., Qiu, X., Yan, Z., John, S., Jonas, L. (2011), "Use of environmental value stream mapping and environmental loss analysis in lean manufacturing work at Volvo", In: Proceedings of the 4th Swedish Production Symposium (SPS11), Lund, Sweden, May 3-5.

Mollenkopf, D., Stolze, H., Tate, W. Ueltschy, M. (2010), “Green, lean, and global supply chains", International Journal of Physical Distribution \& Logistics Management, 40(1/2), 14-41.

National Academy of Engineering (1999), Industrial environmental performance metrics challenges and opportunities, National Academy Press, Washington, D.C.

Pampanelli, A.B., Found, P., Bernardes, A.M. (2011), “A lean and green kaizen model”, POMS annual conference, Nevada, April 29-May 2.

Robson, C., McCartan, K. (2016), Real world research. $4^{\text {th }}$ edition, John Wiley \& Sons, Chichester.

Rocha-Lona, L., Garza-Reyes J.A., Kumar, V. (2013), Building quality management systems: selecting the right methods and tools, Productivity Press, CRC Press, Taylor \& Francis, Boca Raton, FL.

Ross and Associates (2000), "Pursuing perfection: case studies examining lean manufacturing strategies, pollution prevention, and environmental regulatory management implications", US Environmental Protection Agency. 
Rothenberg, S., Pil, F., Maxwell, J. (2001), "Lean, green, and the quest for superior environmental performance", Production and Operations Management, 10(3), 228243.

Shah, R., Goldstein, S. M. (2006), Use of structural equation modeling in operations management research: Looking back and forward, Journal of Operations Management, 24(2), 148-169.

Sarkis, J. (2001), “Manufacturing's role in corporate environmental sustainability: concerns for the new millennium", International Journal of Operations and Production Management, 21(5/6), 666-686.

Saunders, M., Lewis, P., Thornhill, A. (2012), Research Methods for Business Students, 6th ed. Person Education Ltd, Essex.

Shah, R., Ward, P. (2003), "Lean Manufacturing: Context, Practice Bundles, and Performance", Journal of Operations Management, 21(2), 129-149.

Shah, R., Ward, P. (2007), “Defining and Developing Measures of Lean Production”, Journal of Operations Management, 25(4), 785-805.

Shingo, S. (1989), A Study of Toyota Production System: from an Industrial Engineering Viewpoint, Productivity Press, NY.

Simons, D., Mason, R. (2003), "Lean and green: doing more with less", International Commerce Review: ECR Journal, 3(1), 84-91.

Tice, J., Ahouse, L., Larson, T. (2005), “Lean production and EMSs: aligning environmental management with business priorities", Environmental Quality Management, 15(2), 112.

Torielli, R.M., Abrahams, R.A., Smillie, R.W., Voigt, R.C. (2011), "Using lean methodologies for economically and environmentally sustainable foundries", China Foundry, 8(1), pp. 74-88. 
Tachizawa, E.M., Gimenez, C. (2010), “Supply flexibility strategies in Spanish firms: Results from a survey”, International Journal of Production Economics, 124, 214-224.

Vais, A., Miron, V., Pederson, M., Folke, J. (2006), "Lean and green at a Romanian secondary tissue paper and board mill - putting theory into practice", Resources, Conservation and Recycling, 46(1), 44-74.

Venkat, K., Wakeland, W. (2006), Is lean necessarily green? Available at: http://www.cleanmetrics.com/pages/ISSS06-IsLeanNecessarilyGreen.pdf. (Accessed on 08 November 2016).

Vinodh, S., Arvind, K., Somanaathan, M. (2011), "Tools and techniques for enabling sustainability through lean initiatives", Clean Technologies and Environmental Policy, 13(3), 469-479.

Womack, J., Jones, D. (2003), Lean Thinking: Banish Waste and Create Wealth in Your Corporation, Free Press, NY.

Womack, J. P. (2006), "Value Stream Mapping”, Manufacturing Engineering, 136(5), 145156.

Yang, M.G., Hong, P., Modi, S.B. (2011), "Impact of lean manufacturing and environmental management on business performance: An empirical study of manufacturing firms", International Journal of Production Economics, 129(2), 251-261.

Zhu, Q., Sarkis, J. and Geng, Y. (2005). 'Green supply chain management in China: pressures, practices and performance'. International Journal of Operations and Production Management, 25, 449-68.

Zhu, Q., Sarkis, J., Lai, K. (2008), “Confirmation of a Measurement Model for Green Supply Chain Management Practices", International Journal of Production Economics, 111(2), 261-273. 
